Розроблено експериментальні зразки зволожувальних розчинів, до складу яких введено добавки з антибактеріальними властивостями для підвищення продуктивності процесу експлуатації систем зволоження у друкарсъких машинах. Визначено вплив добавок на зміну показників електропровідності та кислотності зволожувальних розчинів під час експлуатації та зберігання розчинів. Досліджено методи обробки зволожувальних розчинів для стабільності їх експлуатаційних властивостей та забезпечення якості друкування поліграфічної продукції

Ключові слова: поліграфічна продукція, офсетний друк, зволожувальний розчин, антибактеріальні добавки, електропровідність, кислотність

Разработаны әкспериментальнье образцы увлажняющих растворов, в состав которых введены добавки с антибактериальными свойствами, обеспечивающие повышение производительности әксплуатации систем увлажнения в печатных маиинах. Определено влияние добавок на изменение показателей электропроводности и кислотности увлажняющих растворов при их әксплуатации и хранении. Исследованы методы обработки увлажняющих растворов для стабильности их эксплуатационных свойств и обеспечения качества печатания полиграфической продукции

Ключевые слова: полиграфическая продукция, офсетная печать, увлажняющий раствор, антибактериальные добавки, электропроводность, кислотность

\section{THE IMPROVEMENT OF DAMPENING SOLUTION FOR OFFSET PRINTING}

O. Vel y c h k o

Doctor of Technical Sciences, Professor

Head of Department*

E-mail: o.velychko@kpi.ua

K. Zolot ukhina

$\mathrm{PhD*}$

E-mail: k.zolotukhina@kpi.ua

T. R o z u m

PhD, Associate Professor*

E-mail: t.rozum@kpi.ua

*Department of reprography

Publishing and Printing Institute of the National Technical University of Ukraine

"Kyiv Polytechnic Institute"

Ak. Yangel str., 1/37, Kiev, Ukraine, 03056

\section{Introduction}

The publishing and printing industry is evolving under the influence of scientific and technological progress. The driving force are the specialized production and personalized products based on modern digital technology, enhancing continuity and flexibility, automation and computerization of publishing and printing systems, the introduction of new digital monitoring and support properties, materials, constant improvement of quality requirements for finished products and so on. Offset printing with printing plates dampening holds a leading position in the production of printing products and is experiencing now all forms of scientific progress $[1,2]$.

The performance and print quality of offset printing with printing plates dampening depend on many factors, and quality of various printing and packaging products, in its turn, in the current environment requires the least aggressive environmental impact.

The most important factors of the printing process are: printing material properties, process conditions and their interaction. Changes in the properties of the components of the technological environment, ignoring of printing parameters can lead to:

- unstable process;

- color reproduction infringement;

- various defects etc.

An important component of offset printing is dampening fluid which should be thoroughly monitored daily [3, 4].
Whereas the constant sharpening of the quality requirements to the printing and packaging products, an urgent task for the further improvement and development of environmentally friendly offset printing with printing plates moistening is to provide regulation of antibacterial properties of the technological environment components, including dampening fluids by introducing antibacterial additives and special processing methods.

2. The analysis of literature and problem definition

The dominance of offset printing with printing plates moistening in the production of printed products contributed to deepening the study of technological printing base, components of the technological environment, establishing patterns of changes in the characteristics of imprints based on the properties of printing substrates, inks, dampening fluids, rubber cloths and printing conditions. Research is focused on the improvement of systems maintaining the stability of technological modes.

Research [5] is based on experimental studies of the composition, structure and properties of offset blankets and their changes under the influence of printing factors and blanket surface wetting changes concerned with the circulation are determined. In particular, the increase in the surface tension of the surface layers leads to disruption of acceptance and transferring of ink and dampening fluid. Thus, when the dampening fluid layer thickness lies within 1.8-3.0 $\mu \mathrm{m}$ new 
offset blankets transfer it to paper as much as possible (70\%). Worn-out offset blankets have a maximum transferring (80\%) only if the dampening fluid layer thickness is $2 \mu \mathrm{m}$ and drops to $33 \%$ with increasing thickness to 2.5 to $5 \mu \mathrm{m}$. Significant differences were found while transferring ink and dampening fluid by worn-out offset blankets. The inks transfer on paper reduces to $40-50 \%$, and the dampening fluid transfer coefficient is $80 \%$ for the same print modes that characterizes ink/water imbalance. Identified narrow limits of the dampening fluid layer thickness during printing with increased circulation lead to the necessity of constant adjustment of printing modes. While reducing the thickness of the dampening fluid on the printing plate surface contributes to greater stabilization of water/ink emulsion, violating its stability depending on offset blankets wearing out is a significant factor in the performance and stability of the printing process.

Printed contact impact factors to the dampening fluid perception and transferring by spacing elements of offset plate which were found in research [6], also substantially violate the ink-water balance. Thus, for the new printing plates the minimal layer held by the spacing elements is $0.25 \mu \mathrm{m}$, and after 70 thousand imprints that layer is only $0.02 \mu \mathrm{m}$, which is caused by changes in porosity, surface microgeometry and spacing elements composition under the printing contact influence factors.

In addition, industrial research of the dampening fluid properties given in [6] found stochasticity of conductivity parameter - a significant increase, then balancing and then increase as a result of the variability of orders and printing machine settings changes.

The study [7-9] presents the dampening fluid transfer process modeling between dampening rollers and film dampening units investigation. The study [9] proposes the method of measuring the dampening fluid for film dampening rollers of the machine, which allows to control the uniformity of the fluid layer for stabilization modes during printing.

Choice of a concentrate of the dampening fluid to achieve optimal formulation for printing on sheet printing machines is revealed in the works [10,11]. The research established that with increasing quantity of the dampening fluid at ink from 1 to $30 \%$, with the ink layer thickness $1.2 \mu \mathrm{m}$, the ink curing time is increased by $25 \%$.

The study [11-13] presents the comprehensive study and prediction of such quality characteristics as optical density, gray balance, tone enhancement modes depending on the dampening fluid supply. In particular, [12, 13] studied the effect of reducing the number of isopropyl alcohol until its complete exclusion from the dampening fluid for quality newspaper printing.

The research described in [5-13], indicate the relationship of component composition of the dampening fluid with its feeding regimes and transfer in printing contact. At the same time, compliance of water-ink balance continues to be relevant. It is known [3] that the $\mathrm{pH}$ of the dampening fluid affects the degree of ink emulsification and curing. Reducing the $\mathrm{pH}$ from 9 to 5 units reduces the degree of emulsification, but increases the drying time up to $50 \%$.

Recent analyses [14] reveal the nature of the functions of automatic selection of the dampening fluid components. Moreover, the operation principles of devices of rinsing and cleaning of dampening units are given. Systems for automated control; and stabilization of the dampening fluid, which are equipped with offset printing machines are popular [14]:
Kompac II/III/V/VI (Varn Kompac); alpha, beta, delta etc. (Technotrans Group;) BasicLiner (BALDWIN); Space Saver SS-3 (Superior Press Parts); Optimizer (Ecografica).

For example, system Optimizer, Italian company Ecografica, according to data published in the source [14], is connected to the dampening fluid recycling system and to the water supply. The system independently prepares a fluid and automatically maintains its parameters. Integrated pump continuously pumps the fluid through the device. In this moment, measuring of the dampening characteristics and if necessary, automatic correction are conducted.

Adjustment of settings is carried out through the use of ion exchange resins. The $\mathrm{pH}$ is regulated by adding the dosed amount of so-called "acid water". It comes from a special tank, where the tap water is exposed to specific components of ion exchange resins and becomes "acidic". Conductivity is controlled by the use of special concentrated solution dispensed drop by drop. Remote setting of the parameters of conductivity and $\mathrm{pH}$ is provided in the system. According to [14], the main material for fluid in this system except tap water is a mixture of resin with the trade name Optires and corporate fluid Optisol for adjusting the conductivity.

Reduction of the surface tension of water is achieved using a special "multistage parallel magnet". As a result, the use of such water in the fluid eliminates the need for isopropyl alcohol. The surface tension of water is located on a level that provides the alcohol, allowing you to print with the same quality - raster point becomes clearer, dies more saturated, colors brighter. Meanwhile, according to [14], magnetic fields significantly inhibit the crystallization of salts in water and microflora also develops slowly. Thus, the dampening fluid remains clean much longer [14].

Equipment of the company Technotrans Group is widespread in manufacturing operations through powerful automated preparation, stabilization and maintenance of alcohol dampening regimes. The packages include the implementation of individual and comprehensive operations, universal solutions. Therefore, the range of the systems varies in the cost and in degree of automation [15]. In Ukraine, the systems of the company Technotrans Group maintained and implemented by Ltd. "MacHOUSE" which publishes all relevant information on its website [16]. An important conclusion that can be done given the sources [14-16], is as follows. Due to the proposed solutions, environmentally friendly printing production is provided, stochasticity is minimized through the preparation and processing of water, the dampening fluid is less vulnerable to the growth of microorganisms, and prevention and cleaning of dampening systems come to the use of branded products.

The problem of purity of the dampening system which is linked to the quality of printed products was found. Research [17-19] provides particular methods of water and the dampening fluid treatment and spent fluid disposal in sheetfed offset printing machines.

Research [17] provides the results of the experimental study of the changes in the key indicators of water and dampening fluids and their influence to the offset printing. In particular, the installation of the water treatment system based on reverse osmosis technology is proposed to improve the technical condition of the equipment, as well as to increase the wear life of ink and dampening units rollers. Research [18] proposes the methods of the dampening fluid treatment by a magnetic field to improve its properties, including offset printing plates and offset rubber-cloth wet- 
ting. One can find a quantitative proportion of ingredients and recommendations how the dampening fluid feed system should be prepared [18]. The disadvantage [18] is the presence of bulky energy-intensive units, which are effective only in a large scaled production and reducing the time of drying of imprints when printing hybrid inks for their varnishing UV varnishes in line.

This paper [19] explores treatment method of waste fountain solution from sheet-fed offset printing. Calcium chlorate is used to have an oxidation treatment for the waste water. But the problem of waste accumulation in the dampening unit of equipment was not considered.

In this article [20], the method for imaging and measuring the amount of the dampening fluid consisting of the waterink emulsion is developed. Its essence is to add fluorescent dyes to the dampening fluid and track the quantity and state of droplets in the emulsion using confocal microscopy. The downside can be considered a distortion of the color characteristics of imprints due to the addition of the dye.

Thus, the problems of selection of the dampening fluid components, preparation of water for fluid, feed and transfer control during printing, interaction with printing plates and offset blankets are relevant and are investigated. However, prevention of the dampening fluid microorganisms, prevention and cleaning of dampening systems have prospects for improvement.

An important area of improvement of dampening may be putting additional antibacterial components at a constant $\mathrm{pH}$ and conductivity of the fluid to facilitate effective prevention of dampening devices. Reducing the formation of microorganisms in the fluid will increase the efficiency of cleaning of the dampening apparatus and stabilization of the water-ink emulsion during printing. This will also expand the range of applications not only in the newest dampening systems, but also in single and duotone printing machines with the older generation film dampening.

The ensuring of environmental protection while printing will always be important, so it is promising to increase the dampening fluid antibacterial properties, while preserving stable acidity, conductivity and total mineralization. Therefore, the research is focused on the development of optimal dampening fluid using special methods for its treatment and analysis of the dampening fluid concentrates antimicrobial additives impact on the stability of its performance for a long period of time and product quality when printing with water-ink emulsion.

\section{The purpose and objectives of research}

The purpose of the study was to determine the impact of antimicrobial additives to the dampening fluid and methods of processing on the stability of indices, such as conductivity and $\mathrm{pH}$ to enhance process productivity of dampening systems exploitation when printing.

To achieve this goal, the following tasks were settled:

- to determine the impact of antimicrobial additives to the dampening fluid and printing process parameters changes;

- to find out the mutual impact of technological environment parameters while transferring of the water-ink emulsion on printing material;

- to improve methods of processing components of technology environment for the printing stabilization and color reproduction normalization.

\section{Materials and methods of the study of additives} influence on the dampening fluid indicators stability

\subsection{Investigated materials and tools that were used} in the experiment

Common in Ukraine dampening fluid concentrates, developed samples of the dampening fluid and hybrid inks shown in Table 1 were investigated.

Indices of conductivity, hardness, acidity were investigated for the fluids (Table 2).

Table 1

Investigated materials

\begin{tabular}{|c|c|c|}
\hline Materials & Brand & The manufacturer (supplier) \\
\hline Concentrate of the dampening fluid & $\begin{array}{l}\text { - Gold Star Fountain Solution; } \\
\text { - Stabilat D; } \\
\text { - Varn Supreme }\end{array}$ & $\begin{array}{l}\text { - ABC Chem (supplier } \\
\text { in Ukraine - APG Printing Technology); } \\
\text { - Druckerei Service supplier } \\
\text { in Ukraine - Ltd "Polihrafimport"); } \\
\text { - Varn (supplier } \\
\text { in Ukraine - Ltd "MacHouse") }\end{array}$ \\
\hline $\begin{array}{l}\text { Dampening fluid based on citric acid, sodium phosphate } \\
12 \text { water, decasan, } 1 \% \text { solution of salicylic acid in } \\
\text { ethanol, } 20 \% \text { solution of sodium tetraborate in glycerol }\end{array}$ & Experimental samples of dampening fluid & Patent of Ukraine № 108080 [21] \\
\hline $\begin{array}{c}\text { Antibacterial additive in } \\
\text { an aqueous solution of decametoxine }\end{array}$ & Decasan & "Yury Pharm" Ukraine \\
\hline $\begin{array}{l}\text { Printing ink based on alkyd polymers, a mixture of } \\
\text { mineral and vegetable oils, cobalt siccative, surfactants, } \\
\text { oligoetheracrylates, photoinitiator, hydroquinone }\end{array}$ & Examples of hybrid inks & Patent of Ukraine № 60660 [22] \\
\hline Paper & $\begin{array}{l}\text { - Offset paper } \\
\text { UPM Gloss, } 80 \mathrm{~g} / \mathrm{m}^{2} ; \\
\text { - Coated paper } \\
\text { Magno Satin Sappi, } 130 \mathrm{~g} / \mathrm{m}^{2}\end{array}$ & $\begin{array}{l}\text { - UPM (supplier } \\
\text { in Ukraine - Ltd “Servisoptorh”); } \\
\text { - Sappi (supplier } \\
\text { in Ukraine - Ltd “Ukrimpap”) }\end{array}$ \\
\hline Plastic sheets & $\begin{array}{c}\text { PVC plastic and } \\
\text { polystyrene plastic sheets } \\
\text { thickness } 0.5 \mathrm{~mm}\end{array}$ & $\begin{array}{c}\text { Pentaprint supplier } \\
\text { in Ukraine - Ltd "Factorial") }\end{array}$ \\
\hline
\end{tabular}


Table 2

Indices and instruments to measure

\begin{tabular}{|c|c|c|}
\hline Indices & Tools (brand, manufacturer) & Specifications of tools \\
\hline Conductivity, $\mu \mathrm{S} / \mathrm{cm}$ & $\begin{array}{c}\begin{array}{c}\text { Conductometer EZODO cond } 5021 \\
(\text { EZO, Taiwan })\end{array} \\
\end{array}$ & $\begin{array}{c}\text { Measurement accuracy of } \pm 2 \% \text { of measured } \\
\text { value in the range } 0-9990 \mu \mathrm{S} / \mathrm{cm}\end{array}$ \\
\hline Hardness, dH & $\begin{array}{c}\text { Solutions quality portable tester TDS meter } 1395 \\
\text { (Kelilong Electron, China) }\end{array}$ & Measurement accuracy of $\pm 2 \%$ of measured value \\
\hline Acidity, $\mathrm{pH}$ & $\begin{array}{c}\text { pH-meter 150 MI } \\
\text { (Ltd "Measuring equipment", Russia) }\end{array}$ & $\begin{array}{c}\text { Measurement accuracy of } \pm 1 \mathrm{pH} \text { value and } \\
\mathrm{pH} \text { measurement range } 1-14\end{array}$ \\
\hline Transmission coefficient, \% & \begin{tabular}{|c|} 
Photocolorimeter 2KFK-MP \\
(Zagorski Optical and Mechanical Plant, Russia) \\
\end{tabular} & Radiation range $315-750 \mathrm{~nm}$ \\
\hline $\begin{array}{c}\text { Ink transferring ratio while transfer- } \\
\text { ring of water-ink emulsion (ink) from } \\
\text { the form on offset blankets and then } \\
\text { on printing material, } K, \%\end{array}$ & $\begin{array}{l}\text { Laboratory printing machine LP-1 } \\
\text { (RI of Printing, Russia) }\end{array}$ & $\begin{array}{l}\text { Printing speed } V=2.5 \mathrm{~m} / \mathrm{s} \\
\text { Pressure } \mathrm{P}=1.11 \mathrm{MPa}\end{array}$ \\
\hline Optical density of imprints & $\begin{array}{l}\text { Spectrophotometer GretagMacbeth Eye-One Pro } \\
\text { (GretagMacbeth AG, USA) }\end{array}$ & $\begin{array}{l}\text { Optical resolution }-10 \mathrm{~nm} \text {, size } \\
\text { devices }-4.5 \mathrm{~mm}, \\
\text { geometry of measurement }-40^{\circ} / 0^{\circ}\end{array}$ \\
\hline Color characteristics of imprints & $\begin{array}{c}\text { Spectrophotometer Datacolor } 110 \mathrm{R} \\
\text { (Datacolor, China) }\end{array}$ & Spectral range $-360-700 \mathrm{~nm}$ \\
\hline Treating with magnetic field & $\begin{array}{c}\text { Funnel-magnetron } \\
\text { (STC Magnetrons, Russia) }\end{array}$ & Magnetic induction of $40 \pm 10 \mathrm{mT}$ \\
\hline Exposure & $\begin{array}{l}\text { Quartz lamp BactoSfera OBB 15P } \\
\text { (BactoSfera, Ukraine) }\end{array}$ & UV spectral range $200-400 \mathrm{~nm}$ \\
\hline
\end{tabular}

Preparation of the concentrate based dampening fluid was performed by dissolving it with water in proportions 1:20-1:50, to set the $\mathrm{pH}$ level within 4.7-5.5 (curve 1, Fig. 1). However, the resulting solution needed additional components to bring conductivity to a level of $800-1500 \mu \mathrm{S} / \mathrm{cm}$ (curve 2, Fig. 1). The desired level of conductivity of the solution was reached by the addition of antibacterial agents and isopropyl alcohol.

Transmittance measure, $\mathrm{pH}$, conductivity of the dampening fluid was determined over 720 hours of storage in the laboratory at a temperature of $18-20{ }^{\circ} \mathrm{C}$ and humidity of $60 \%$.

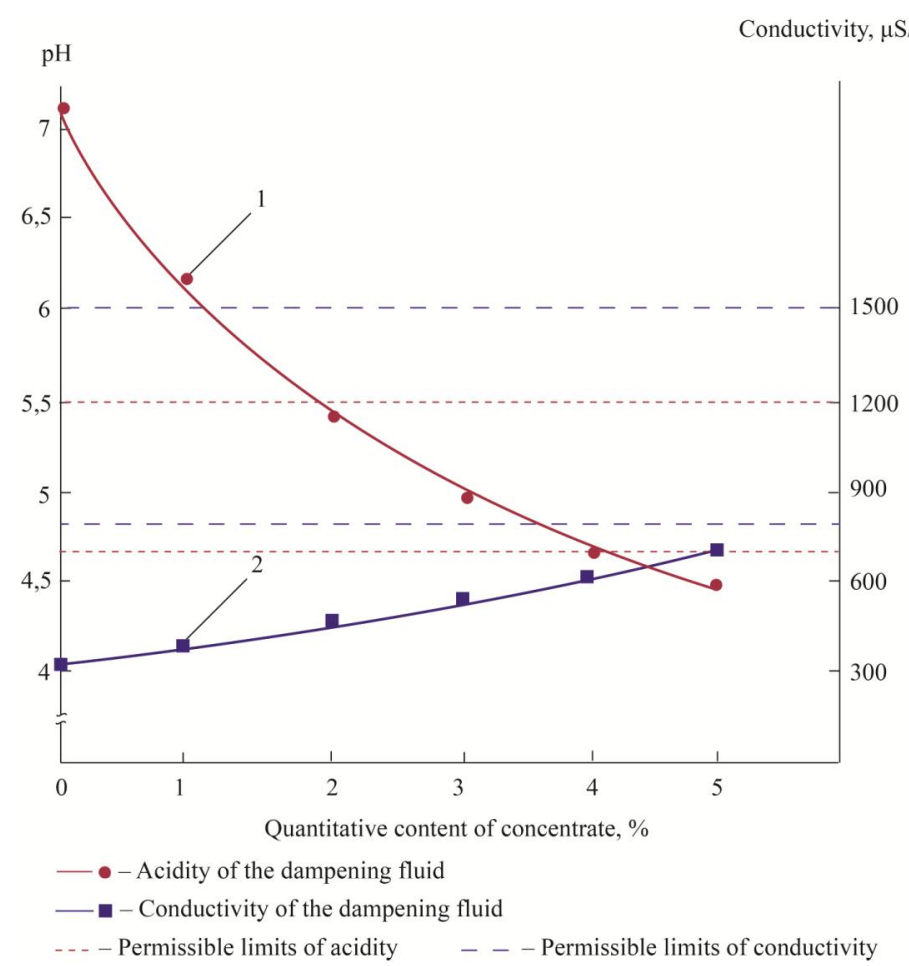

Fig. 1. Dampening fluid acidity changes (1) and conductivity changes (2) depending on the quantitative content of the concentrate
To create a water-ink emulsion, prepared dampening fluid was added in an amount of $25 \%$ (ratio 1:4) to model hybrid ink. A balanced mix of ink and water provides a stable emulsion which is important for offset printing. And all deviations lead to problems when printing. Emulsification significantly influences the properties of inks, their viscosity, stickiness, and thixotropic properties. It can decrease the intensity of color, change inks' spectral characteristics, color coverage etc. Transferring of the water-ink emulsion in printing contact with antimicrobial additives to the dampening fluid is an important aspect of the study.

Printing was carried out with the water-ink emulsion on a laboratory printing machine LP1on paper and plastic sheets (Table 1 ) with the following parameters: speed of $2.5 \mathrm{~m} / \mathrm{s}$, the pressure of $1.11 \mathrm{MPa}$. Ink transferring coefficient was determined by the method [23]. The optical density and color characteristics of prints were measured (Table 2). Statistical analysis of experimental data was based on the determination of standard deviation and absolute error by the method [23]. Calculations were made in the Microsoft Excel 2010 software [23].

\section{2. Methods of processing dampening flu-} id samples

During printing or storage in the interoperable period, the dampening fluid can change its properties as noted above in p. 2. In particular, $\mathrm{pH}$ changes, conductivity increases, foaming begins and the solution becomes brown. The result is disrupted water-ink balance and worse printing quality.

To ensure the stability, additional magnetic field processing was used by passing through the magnetic funnel with magnetic induction of $40 \pm 10 \mathrm{mT}$ and an additional exposure in the UV spectral range $200-400 \mathrm{~nm}$ for $10-30 \mathrm{~min}-$ utes was conducted (Table 2). 


\section{The research results of the major parameters of dampening fluids and their interaction with the printing ink in printing contact}

Antimicrobial additive supplement into the solution results in increased conductivity and has virtually no impact on the acidity of the dampening fluid (curve 1, Fig. 2). As the dampening fluid conductivity (curve 2, Fig. 2) must be in a clearly defined limit, the study identified the optimal 3-6\% content of additives to maintain the conductivity value in the range of $800-1500 \mu \mathrm{S} / \mathrm{cm}$.

During 720 research hours, the conductivity changes of the dampening fluid prepared from well-known manufacturer concentrate (Table 1) were within $\pm 30-70 \mu \mathrm{S} / \mathrm{cm}$ and went beyond the normal range, while the electrical conductivity of the pretreated developed solutions varied within $\pm 10-30 \mu \mathrm{S} / \mathrm{cm}$ which corresponded to the standardized values.

Acidity of the dampening fluid prepared from famous manufacturer concentrate (Table 1 ) changed by $\pm 0.1-0.3$ units, and acidity of the developed sample with additives ranged from $\pm 0.02-0.04$, which are minor and do not affect the quality of the dampening fluid and do not violate the stability of the printing process.

Solutions aging after magnetic field and UV-radiation treatment decreased slightly, as illustrated in Fig. 3, 4.

Evidently, when stored over 720 hours, the dampening fluid based on a known manufacturer concentrate Gold Star Fountain Solution (Table 1) without treatment has a greater degree of turbidity (curve 1, Fig. 3, 4) than solution with antibacterial additives and treatment (curves 2-4, Fig. 3,4), indicating the appropriateness of their application.

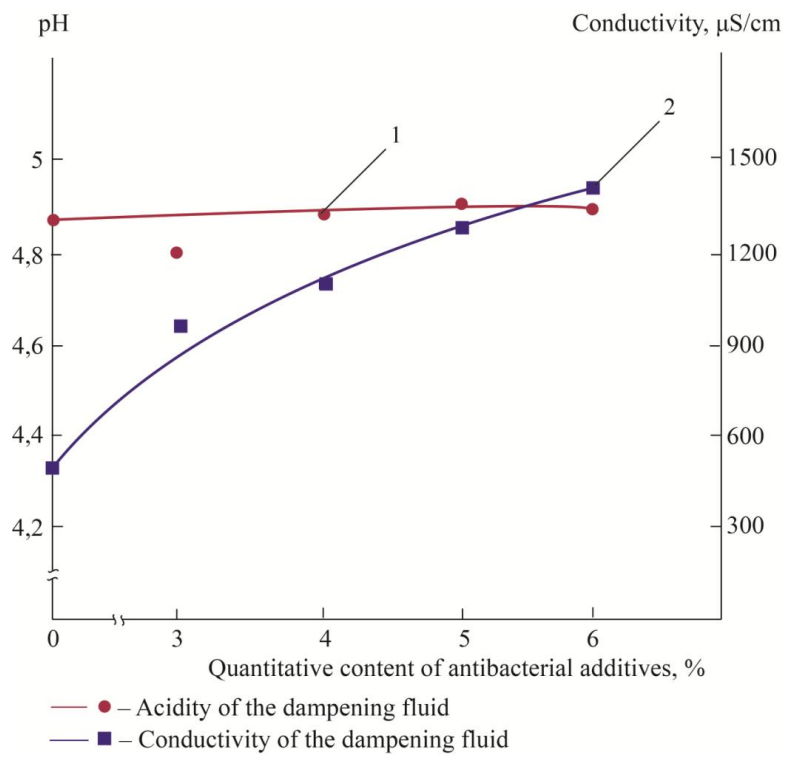

Fig. 2. Dampening fluid acidity changes (1) and conductivity changes (2) depending on quantitative content of antibacterial additives
Developed and prepared for printing dampening fluid samples were used to study the technical characteristics of imprints when printing with water-ink emulsion.

The normalized under ISO 12647 [24] optical density of the imprint obtained by offset printing on the nonabsorbent substrate is achieved when the ink layer thickness is $1-1.6 \mu \mathrm{m}$, and when printing on materials with porous structure $-1.5-2.0 \mu \mathrm{m}$.

However, the developed samples and forming a stable water-ink emulsion provided a normalized value of optical density when printing thin $0.8-1.0 \mu \mathrm{m}$ thickness layers.

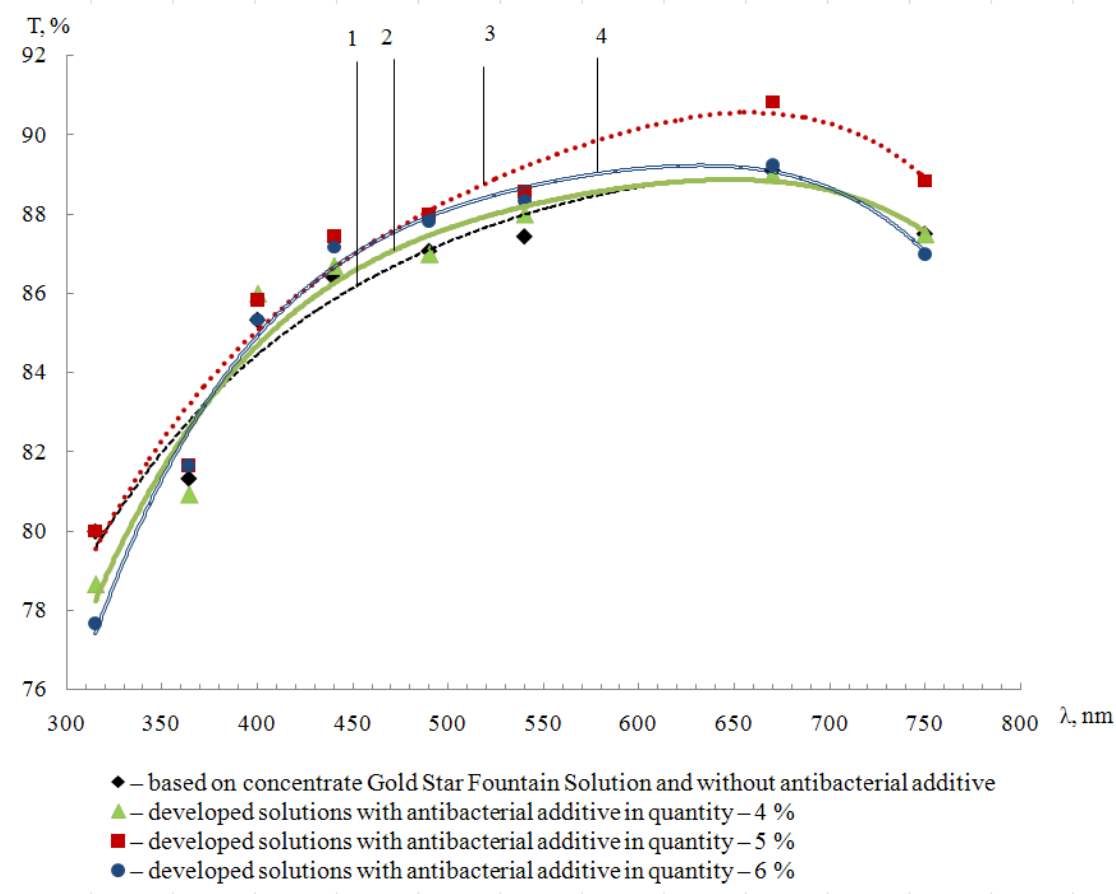

Fig. 3. Dampening fluid transmission coefficient in the radiation range of $300-750 \mathrm{~nm}$ immediately after preparing

Studies have shown the general pattern of interaction of paper and ink in the printing contact that meets established phenomena [3]. Ink-receptivity ratio depends on the paper surface, so in case of equal modes of printing on coated paper, it has a wider range of the ink layers thickness on the form (Fig. 5).

Curve 1 (Fig. 5) is described by the equation:

$$
y=-13.96 x^{2}+37.89 x+5.8,
$$

approximation value $\mathrm{R}^{2}=0.92$, Curve 2 (Fig. 4 ) is described by the equation:

$$
y=-7.68 x^{2}+31.4 x+0.42, R^{2}=0.92 .
$$

Studies have shown that ink receptivity ratio when printing on non-adsorbent substrates is slightly higher for hybrid paint with more UV components (Fig. 6). However, the nature of the curves $\mathrm{K}=\mathrm{f}\left(\mathrm{h}_{\mathrm{i}}\right)$ is much more extreme at a narrower range of ink layers on the form and is described by the following polynomial equations of the second order:

$$
\begin{aligned}
& \text { curve 1: } y=-92.35 x^{2}+20.99 x+52.4, R^{2}=0.94 ; \\
& \text { curve } 2: y=-56.87 x^{2}+4.42 x+48, R^{2}=0.84 ;
\end{aligned}
$$


curve 3: $y=-306.07 x^{2}+308.74 x-29.86, R^{2}=0.95$;

curve $4: \mathrm{y}=-302.02 \mathrm{x}^{2}+239.01 \mathrm{x}+4.4, \mathrm{R}^{2}=0.93$

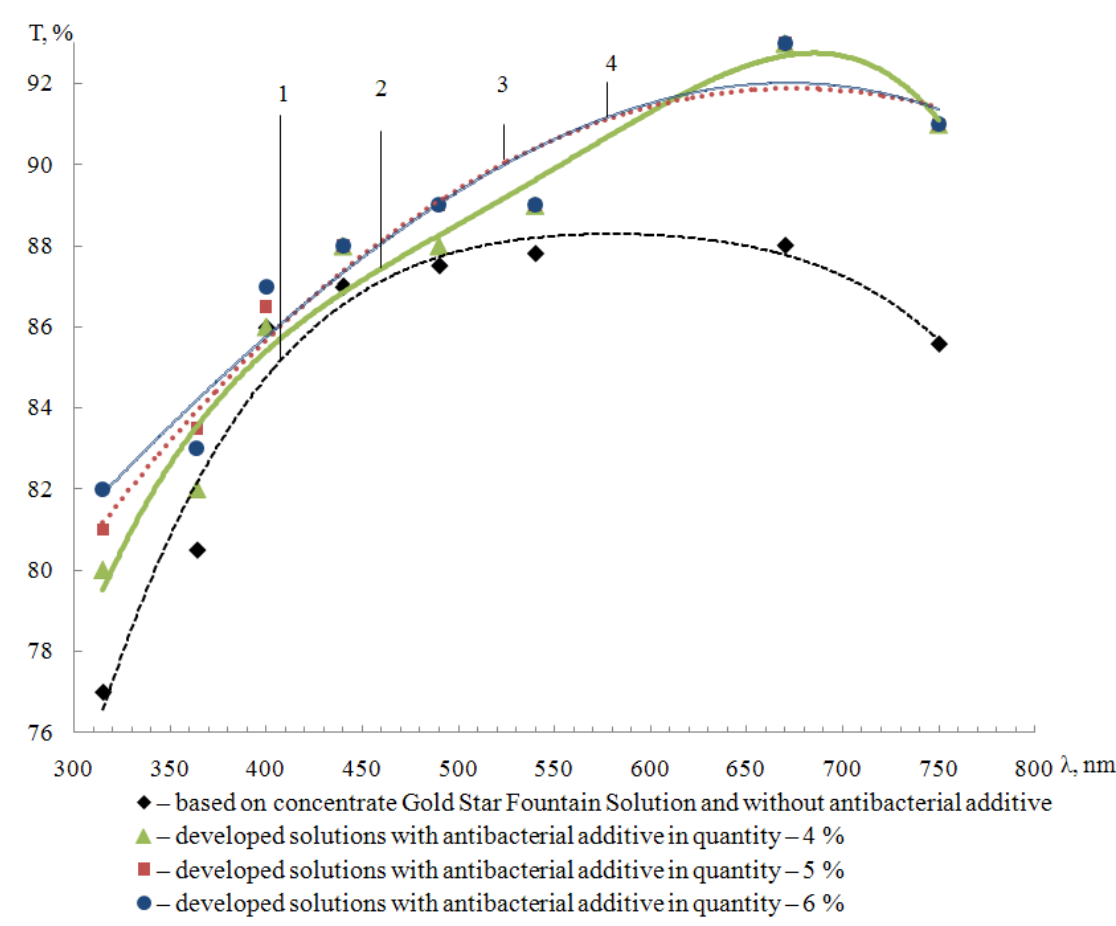

Fig. 4. Dampening fluid transmission coefficient in the radiation range of $300-750 \mathrm{~nm}$ after 720 hours of storage

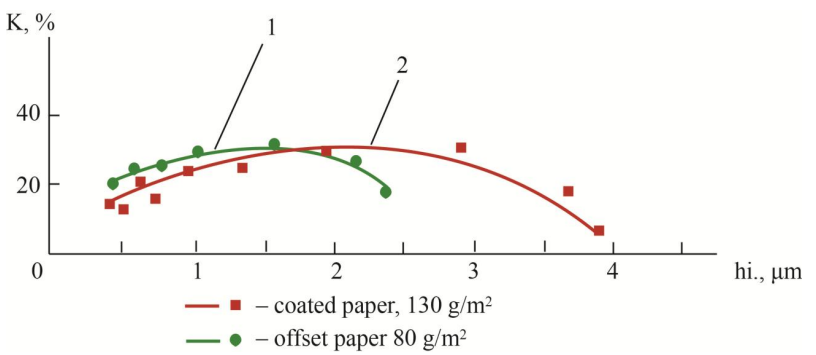

Fig. 5. Dependence of ink transferring ratio $(K)$ and thickness of ink layer on the form $\left(h_{i}\right)$ when printing with water-ink emulsion ink using hybrid ink: 1 - offset paper $80 \mathrm{~g} / \mathrm{m}^{2}$; 2 - coated paper, $130 \mathrm{~g} / \mathrm{m}^{2}$

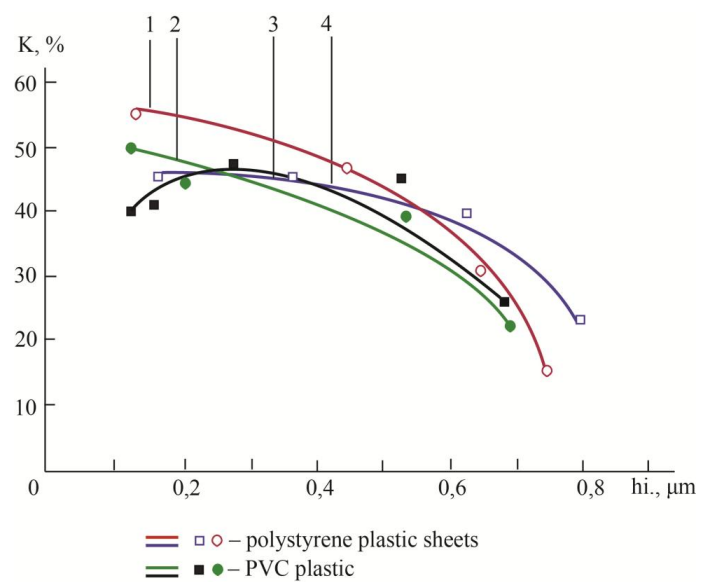

Fig. 6. Dependence of ink transferring $(\mathrm{K})$ and ink thickness on the form $\left(h_{i}\right)$ when printing by water-ink emulsion using hybrid paint with the UV component quantity: $1,2-2 \%, 3,4-10 \%$; 1, 3 - polystyrene plastic sheets; 2,4 - PVC plastic
The experimental data revealed that the process of printing by ink-water emulsion provides normalized absorbance values of imprints when applying layers of ink to $1 \mu \mathrm{m}$. This value of the thickness of ink layers on the imprint is optimal because it provides the minimum allowable value of color differences $\Delta \mathrm{E}$ under ISO 12647 [24]. For offset paper, the thickness of the ink's layer is $0.5-1.0 \mu \mathrm{m}$ for coated $-0.8-1.0 \mu \mathrm{m}$, for non-absorbent materials $-0.5-0.8 \mu \mathrm{m}$. Using model inks, antimicrobial additives to the dampening solution can reduce the cost of inks, improve the environmental aspects and get the color according to the standard ISO 12647-2:2004 [24], and carry out drying of imprints with lower energy costs.

Analysis of measurements of the optical density and the time of initial curing of imprints obtained by water-ink emulsion indicates that additional supplement of antibacterial additives and dampening fluid pre-treatment ensure the stability of water-ink emulsion, normalizes the optical density on the imprint, and reduces the time of initial ink curing before palletizing by $5-8$ minutes.

\section{Discussion of research results of the major parameters of dampening fluids and their interaction with the ink in printing contact}

Improving dampening processes is the subject of successive actions on water treatment, analysis of the current range of concentrates for preparing the dampening fluid and additives for adjusting their properties depending on the characteristics of water and technological environment of the printing contact, structure of printing materials and plot images, and deciding on a particular component.

Analysis of measuring changes in $\mathrm{pH}$ and conductivity shows the feasibility of the introduction of antibacterial additives, including decasan amounting to $3-6 \%$ to the dampening fluid. Decasan adding reduces the formation of harmful microorganisms. It becomes possible to handle more orders due to reduced time to clean the dampening unit.

Thus, the dampening system productivity increases. Dampening fluid magnetic treatment and UV radiation treatment under the UV spectral range 200-400 nm during 10-30 minutes ensure the stability of fluid properties during 720 hours of storage. Reduced time of initial hybrid ink curing by $5-8$ minutes (twice) helps to treat UV varnishes in line with the normalized optical density indicators. Normalized optical density when printing thin layers with a thickness of $0.8-1.0 \mu \mathrm{m}$ provides great opportunities to enhance printing process productivity, such as plastic packaging production and stacking up to 1.000 sheets.

The research results will be useful for printers that include, among the entire spectrum of production capacities, the station for offset printing with dampening. Production of printed and packaging products using the 
proposed solutions will conform to the environmental and printing standards.

The research is one of many topics of printing direction. Tests of established experimental models of dampening fluids will be continued and aimed at a thorough definition of the time needed to setup ink and dampening units, cleaning them from residuals of waste components while changing orders and dampening system maintenance.

\section{Conclusions}

1. Directions of improving dampening in offset printing, including antibacterial additives adding and methods of flu- id processing to improve the dampening system performance for printing printed products are determined.

2 . The $3-6 \%$ quantity of antimicrobial additive to maintain the value of conductivity in the normal $800-1500 \mu \mathrm{S} / \mathrm{cm}$ range was defined. The results of research of interaction between the components of the ink-water emulsion gave grounds to confirm the predicted interaction of the characteristics of the technological environment of printing contact when printing layers of ink with a thickness within 0.5-1.0 microns on high-performance equipment.

3. Dampening fluid magnetic treatment and UV radiation treatment under the UV spectral range $200-400 \mathrm{~nm}$ provided ink-water balance stability, normalized optical density of the imprint and reduced time of initial ink curing by $5-8$ minutes.

\section{References}

1. Kuznetsov, Y. V. Basics illustrative printing technology [Text] / Y. V. Kuznetsov. - Sankt-Peterburg: Russian literature, 2016. - 440 p.

2. Zorenko, Y. Improving the technology of reproduction offset printing [Text] / Y. Zorenko; O. M. Velichko (Ed.). - Kiev: PPC Kiev University, 2015. - $176 \mathrm{p}$.

3. Melnikov, O. V. Flat offset printing technology [Text] / O. V. Melnikov. - Lviv: Ukrainian Academy of Printing, 2007. - 388 p.

4. Khohlova, R. A. Finishing printed products of varnishing [Text] / R. A. Khohlova, O. M. Velychko. - Kiev: PPC Kiev University, 2014. - 183 p.

5. Gavrysh, A. Technical analysis of the system "printing form - offset rubber fabric canvas - imprint" [Text] / A. Gavrysh, O. Zorenko // Technology and Technique of Typography. - 2007. - Issue 3-4 (17-18). - P. 36-40.

6. Skyba, V. M. Printing stability of offset printing plates [Text] / V. M. Skyba // Technology and Technique of Typography. - 2015. Issue 1 (47). - P. 30-39. - Available at: http://ttdruk.vpi.kpi.ua/article/view/43272/39745

7. Orlova, E. Y. Study feed dampening solutions with low content of isopropyl alcohol feeding group dampening unit [Text] / E. Y. Orlova, E. V. Vulkanov // Journal of the Moscow State University of Printing. - 2014. - Issue 1. - P. 144-147. - Abailable at: http:// cyberleninka.ru/article/n/issledovanie-podachi-uvlazhnyayuschih-rastvorov-s-malym-soderzhaniem-izopropilovogo-spirta-pitayuscheygruppoy-uvlazhnyayuschego

8. Blagodir, O. Regularities of ink-water balance stability in offset printing [Text] / O. Blagodir, K. Zolotukhina, B. Kushlyk, O. Velychko // EUREKA: Physics and Engineering. - 2016. - Issue 3. - P. 31-37. doi: 10.21303/2461-4262.2016.00078

9. Uhlev, A. Methods of measurement fountain solution on the roller film dampening systems [Text] / A. Uhlev, I. Hertsenshteyn, E. Orlova // Journal of the Moscow State University of Printing. - 2015. - Issue 1. - P. 165-167. - Available at: http://cyberleninka.ru/ article/n/sposob-izmereniya-uvlazhnyayuschego-rastvora-na-valikah-plenochnogo-uvlazhnyayuschego-apparata

10. Nechiporenko, N. A. The choice of the concentrate and to determine the optimal formulation of fountain solution for sheetfed offset printing [Text] / N. A. Nechiporenko, A. V. Berdovschikova, M. A. Bozojan // Proceedings of the higher educational institutions. Problems of printing and publishing. - 2013. - Issue 6. - P. 30-42.

11. Bozojan, M. A. Influence of dampening conditions on the color characteristics of imprints in sheet-fed offset printing [Text] / M. A. Bozojan, N. A. Nechiporenko // Proceedings of the higher educational institutions. Problems of printing and publishing. - 2015. Issue 3. - P. 14-22. - Available at: http://mgup.ru/article/1840

12. Mikalainis, P. The Influence of Formulating a Damping Solution on Dot Gain [Text] / P. Mikalainis, J. Sidaravičius, V. Turla // Mokslas Lietuvos Ateitis. Science - Future of Lithuania. - 2010. - Vol. 2, Issue 4. - P. 18-23. doi: 10.3846/mla.2010.061

13. Rossitza, S. Offset Printing without Isopropyl Alcohol in Damping Solution [Text] / S. Rossitza // Energy Procedia. - 2015. - Vol. 74. P. 690-698. doi: 10.1016/j.egypro.2015.07.804

14. Gorova, A. Modern system of automatic control and regulation parameters wetting solution [Text] / A. Gorova // Kvalilogiya of the book. - 2011. - Issue 2. - P. 79-83. - Available at: http://nbuv.gov.ua/UJRN/Kk_2011_2_11

15. Technotrans Group [Electronic resource]. - Available at: http://www.technotrans.com/en/industries/printing-industry/sheet-fedoffset/dampening-solution-circulators-inking-unit-temperature-control/betac.html

16. Technotrans [Electronic resource]. - MacHOUSE. - Available at: http://machouse.ua/brands/TECHNOTRANS.html

17. Kopailenko, I. V. The impact of water quality on the property of dampening solution offset printing [Text] / I. V. Kopailenko // Technology and Technique of Typography. - 2012. - Issue 4 (38). - P. 116-122. - Available at: http://ttdruk.vpi.kpi.ua/article/view/32217/28875

18. Estrina, M. V. Influence of treatment the magnetic field on properties of wetting solution [Text] / M. V. Estrina, V. O. Kanagin // Technology and Technique of Typography. - 2010. - Issue 4 (30). - P. 182-186. - Available at: http://ttdruk.vpi.kpi.ua/article/ view $/ 55768$

19. Li, L. F. Studies on Treatment of Waste Fountain Solution from Sheet-Fed Offset Printing [Text] / L. F. Li, W. M. Wang, C. X. Liao, Y. Y. Zhou, J. H. Gong // Applied Mechanics and Materials. - 2015. - Vol. 731. - P. 321-324. doi: 10.4028/www.scientific.net/ amm.731.321

20. Fuping, L. Ink-fountain Solution Emulsion in Offset Printing Studied Using Confocal Microscopy [Text] / L. Fuping, P. Ian, S. Wei // Appita Journal: Journal of the Technical Association of the Australian and New Zealand Pulp and Paper Industry. - 2008. - Vol. 61, Issue 6. - P. 461-467. - Available at: http://www.worldcat.org/title/ink-fountain-solution-emulsion-in-offset-printing-studied-usingconfocal-microscopy/oclc/4822614745\&referer=brief_results 
21. Patent of Ukraine No 108080. IPC (2016.01) B41N 3/08 (2006.01), B41N 3/00. Wetting solution for flat offset printing [Text] / Velychko O., Zagorodni R., Zolotukhina K. et. al. - No u201601782, declared: 25.02.2016; published: 24.06.2016, № 12

22. Patent of Ukraine No 60660. IPC(2011.01) C09D 11/10 92006.01), B41M 1/00, B41M 3/00. Ink for offset printing [Text] / Velychko O. Zorenko Y., Savchenko K. et. al. - No u201014392, declared: 01.12.2010; published: 25.06.2011, № 12

23. Batrak, A. Planning and Organization experiment [Text] / A. Batrak. - Krasnojarsk: PPC SFU, 2007. - 60 p.

24. ISO 12647-2:2008. Graphic technology - Process control for the production of half-tone colour separations, proof and production prints Part 2: Offset lithographic processes [Text]. - Kyiv: Derzhspozhyvstandart Ukrainy, 2010.

\begin{abstract}
Досліджено можливість змічнення склокристалічних покриттів при одночасній дї трьох видів модифікаторів $\left(\mathrm{ZnO}, \mathrm{TiO}_{2}, \mathrm{SnO}_{2}\right)$. Експериментально виявлено вплив концентраиії кожного з трьох оксидів-модифікаторів на фазові перетворення покриттів в процесі термообробки. Запропоновано механізм дії оксидівмодифікаторів на утворення та зростання зародків кристалів отриманих фаз. Тонкі кристалічні фази, які іммобілізовані до скломатриці, сприяють утворенню однорідноі ситалоподібної структури. При цьому досягається співмірність часток, яка дозволяе одержати матеріал із високими мічносними і термомеханічними властивостями
\end{abstract}

Ключові слова: скломатриия, оксиди-модифікатори $\left(\mathrm{ZnO}, \mathrm{TiO}_{2}, \mathrm{SnO}_{2}\right)$, тонкі кристалічні фази, міцносні і термомеханічні властивості

Исследована возможность упрочнения стеклокристаллических покрытий при одновременном действии трех видов модификаторов $\left(\mathrm{ZnO}, \mathrm{TiO}_{2}, \mathrm{SnO}_{2}\right)$. Экспериментально выявлено влияние концентрации каждого из трех модификаторов на фазовые превращения в проиессе термообработки покрытий. Предложен механизм действия оксидов-модификаторов на образование и рост зародышей кристаллов образующихся фаз. Тонкие кристаллические фазы, которые иммобилизованы в стекломатрицу, способствуют образованию однородной ситаллоподобной структуры. При этом достигается соразмерность иастии, позволяющая получить материал с высокими прочностными и термомеханическими свойствами

Ключевые слова: стекломатрича, оксидымодификаторы $\left(\mathrm{ZnO}, \mathrm{TiO}_{2}, \mathrm{SnO}_{2}\right)$, тонкие кристаллические фазы, прочностные и термомеханические свойства

\section{Introduction}

Glass-crystalline coatings with increased strength are a new class of high resource materials, characterized by unique technological and operational properties. Microstructure of these materials is determined by technological parameters of their obtaining, by the type of modifying additives, even distribution of phases in a glass matrix.

Introduction of modifying additives affects primarily regulation of the processes of phase creation, obtaining of

\section{EFFECT OF MODIFIED GLASS MATRICES ON THE STRENGTHENING OF GLASS CRYSTALLINE COATINGS}

\author{
G. Lis a ch u k \\ Doctor of Technical Sciences, \\ Professor, Head of the research part* \\ E-mail: lisachuk@khpi.kharkov.ua \\ R. K rivobok \\ $\mathrm{PhD}$, Deputy head of the research part* \\ E-mail: krivobok@khpi.kharkov.ua \\ L. Bilostotska \\ Senior Researcher* \\ E-mail: tyud48@ukr.net \\ Y. Trusova \\ Senior Researcher* \\ E-mail: trusova-y@ukr.net \\ L. Pavlova \\ Senior Researcher* \\ E-mail: pavlova-luda50@ukr.net \\ K. Podch a sova \\ Junior Researcher* \\ E-mail: tripodkat@ukr.ua \\ *Department of engineering ceramics, \\ refractories, glass and enamel \\ National Technical University \\ «Kharkiv Polytechnic Institute» \\ Bagalia str., 21, Kharkiv, Ukraine, 61002
}

microcrystalline dense structure of the material with the required strength of glass matrices.

A special place in the creation of high-strength glass-crystalline coatings is taken [1] by the compounds of refractory d-transitive metals of groups II, IV of the periodic table of elements.

This is linked to the peculiarities of their crystallochemical structure:

- these metals lack electrons on the internal s, p and d-orbitals; this leads to the fact that they can easily take 